\title{
MATHEMATICAL SIMULATION PARAMETERS FOR DRYING OF CASSAVA STARCH PELLETS
}

\section{FABIAN L. MORENO ${ }^{1}$, ALFONSO PARRA-CORONADO ${ }^{2}$, JESUS H. CAMACHO- TAMAYO ${ }^{3}$}

\begin{abstract}
Based on experimental tests, it was obtained the equations for drying, equilibrium moisture content, latent heat of vaporization of water contained in the product and the equation of specific heat of cassava starch pellets, essential parameters for realizing modeling and mathematical simulation of mechanical drying of cassava starch for a new technique proposed, consisting of preformed by pelleting and subsequent artificial drying of starch pellets. Drying tests were conducted in an experimental chamber by varying the air temperature, relative humidity, air velocity and product load. The specific heat of starch was determined by differential scanning calorimetry. The generated equations were validated through regression analysis, finding an appropriate correlation of the data, which indicates that by using these equations, can accurately model and simulate the drying process of cassava starch pellets.
\end{abstract}

KEYWORDS: specific heat, latent heat vaporization, moisture equilibrium content, rate drying.

\section{PARÂMETROS PARA SIMULAÇÃO MATEMÁTICA DE SECAGEM DE PELLETS DE FÉCULA DE MANDIOCA}

RESUMO: Com base nos ensaios experimentais foram obtidas as equações de velocidade de secagem, conteúdo de umidade em equilíbrio, calor latente de vaporização da água contida no produto e a equação de calor especifico dos pellets de fécula de mandioca, parâmetros essenciais para realizar a modelagem e simulação matemática de secagem mecânica de amido de mandioca para uma nova técnica proposta, que consiste na pré-formação por peletização e subsequentes secagem artificial dos pellets amido. Foram realizados testes de secagem em uma câmara experimental, variando temperatura do ar, umidade relativa, velocidade do ar e carga do produto.

O calor específico do amido foi determinado por calorimetria de varrimento diferencial. As equações geradas foram validadas por meio de análise de regressão, encontrando a adequada correlação de dados, o que indica que, utilizando tais equações podem ser modelados e simulados com precisão o processo de secagem de pellets de fécula de mandioca.

PALAVRAS-CHAVE: calor específico, calor latente de vaporização, conteúdo de umidade em equilíbrio, velocidade de secagem.

\section{INTRODUCTION}

Cassava (Manihot esculenta crantz), known as Cassava or manioc, is a woody shrub whose roots are in one of the most important sources of energy in tropical regions of the world (Ceballos, 2002). Cassava is appreciated because it has adequate adaptation to different ecosystems, high tolerance to drought and high strength against pests. Colombia has achieved crop yields equal to international standards of $15 \mathrm{t}$ ha- 1 and even experimental yields of up to $90 \mathrm{t} \mathrm{ha}^{-1}$ (ALARCON \& DUFOUR, 2002), whereby broad opportunities in the sector development are emerging. One of the

\footnotetext{
${ }^{1}$ Ingeniero Químico, M.Sc, Profesor Programa de Ingeniería de Producción Agroindustrial, Universidad de La Sabana. Campus Universitario del Puente del Común, Km 7 Autopista Norte de Bogotá, Chía/ Colombia, Fone: (571) 8615555 - 25221 , leonardo.moreno@unisabana.edu.co

${ }^{2}$ Ingeniero Agrícola, Ph. D., Profesor Titular, Universidad Nacional de Colombia, Facultad de Ingeniería, Departamento de Ingeniería Civil y Agrícola, Bogotá D.C., aparrac@unal.edu.co

${ }^{3}$ Ingeniero Agrícola, Ph. D., Profesor Asociado, Universidad Nacional de Colombia, Facultad de Ingeniería, Departamento de Ingeniería Civil y Agrícola, Bogotá D.C., jhcamachot@unal.edu.co 
advantages of cassava is a great variety of products obtained wherefrom; one of the most important is starch, which has huge market worldwide and from which products used in adhesives, textile, paper, pharmaceutical and food industries are obtained.

In Colombia starch is obtained mostly in rural low-tech agribusiness by washing and grated cassava roots and subsequent drying, performed mainly on sunlight courtyards, because the low levels of investment in the sector. The absence of low-cost technologies available for drying starch hinders the increase in levels of productivity and quality of small and medium agribusinesses in Colombia. ARISTIZABAL et al. (2007) proposed a new technique for the drying of starch consisting in a preformed by pelletizing at the post-sedimentation stage by channels, in which the starch has a moisture content of $45 \%$. This enables driving a bed of particulate material into cylindrical pellets with extra granular high porosity on which is possible to send an air flow tangential (or transverse) movement without entrainment of powder present, increasing the drying rate and allow use driers simple and economical designs. The technique is described in Figure 1.

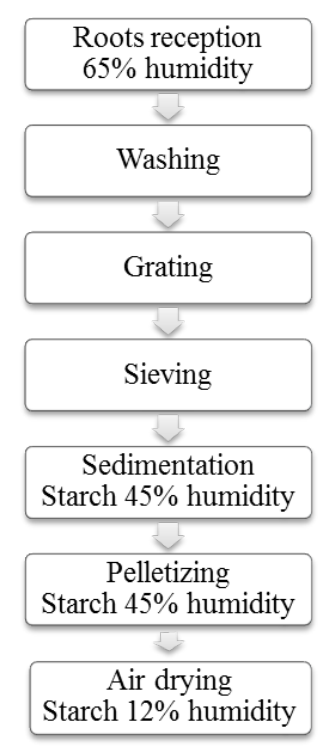

(a)

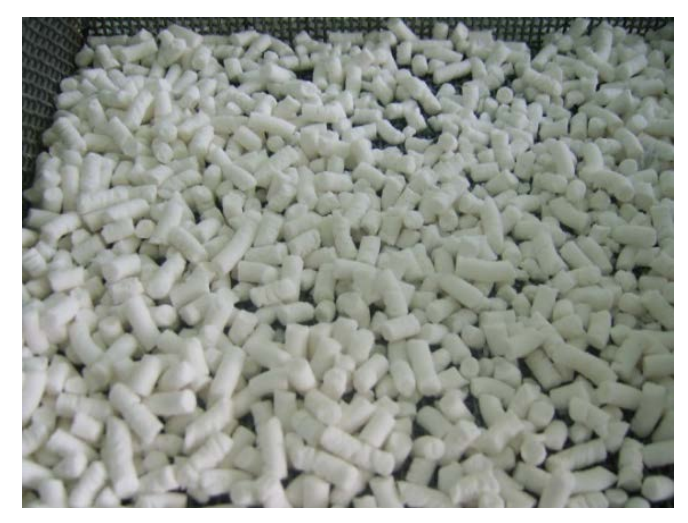

(b)

FIGURE 1. Diagram of the proposed technique for the extraction and drying of cassava starch (a) and cassava starch pellets obtained (b).

Therefore, it is important to encourage the use of drying techniques more efficient, as is the case of mechanical or artificial drying, which can obtain benefits such as reduced labor, reduced drying time and conservation quality, so as to obtain products that fulfill the quality requirements demanded by the international market. In the world every day increases mechanical drying systems for agricultural products, for reasons of reduced risks, costs and better control of production (PARRA-CORONADO et al, 2008). In order to obtain efficient drying systems for agricultural products, It must be known how to properly operate (thickness of the product layer, suitable air flow and temperature). Knowledge of these operating conditions can be investigated by experimental studies, procedure that can take several years, besides being wasteful and expensive (PARRACORONADO et al, 2008). It has been universally demonstrated (MONTES MONTES et al, 2008, DALPASQUALE \& SPERANDIO, 2010; BROOKER et al, 1992;. CENKOWSKI et al., 1993, THOMPSON et al, 1968;.. PARRA-CORONADO et al, 2008) that the mathematical simulation of drying is a viable alternative both technologically and economically, reason why it constitutes a highly effective design tool starch mechanical dryers. By this method it is possible to analyze the predictions of the behavior of starch pellets and make recommendations for the design and operation of drying systems (PARRA-CORONADO et al., 2008). 
The parameters defining the removal of moisture from a product into an air stream or to the environment are: moisture content at the equilibrium, the heat latent of water vaporization contained in the product, the specific heat and the drying rate . Several researchers such as ROA (1974), THOMPSON (1968) and BAKKER-ARKEMA et al. (1974) cited by PARRA-CORONADO et al. (2008) have developed theoretical or semi-empirical mathematical models that incorporate these parameters in the simulation processes drying of agricultural products. Authors such as VEGA \& LEMUS (2006), DA SILVA et al. (2008), PARRA-CORONADO et al. (2008), DALPASQUALE et al. (2009), CHAYJAN \& ESNA-ASHARI, 2010 and DALPASQUALE \& SPERANDIO (2010) and others have generated and/or used parameters for the mathematical simulation of drying various agricultural products, presenting consistent results with the experimental data.

Based on the above, the main objective of this study was to obtain the parameters for the mathematical simulation of the drying pellet cassava starch, for the purpose of generating knowledge that allows dimension and operate efficiently mechanical dryers for this product.

\section{MATERIALS AND METHODS}

This research was carried out in the Laboratory of Chemical Engineering at National University of Colombia in Bogota. Industrial cassava starch Proyucal 4701 was used, from which cylindrical pellets were obtained (through a process of palletizing) with the following characteristics: $5 \mathrm{~mm}$ in diameter; $10 \mathrm{~mm}$ in length; porosity of 0.5 ; moisture content 45\%; $\mathrm{pH} 4,5$ 7.0; gelatinization temperature of $67{ }^{\circ} \mathrm{C}-71^{\circ} \mathrm{C}$; ashes $0.12 \%$. It was set up for all tests an air flow parallel to the bed of starch pellets, according to the results of preliminary tests conducted.

An experimental drying chamber designed and constructed for this purpose was used to carry out experimental tests of equilibrium moisture content and drying rate. The equipment provides a air flow, relative temperature and humidity controlled and records the weight loss of the product over time. The drying equipment scheme shown in Figure 2.

\section{Equilibrium moisture content equation}

The equilibrium moisture content $(\mathrm{Me})$ is defined as the moisture content which reaches the product when it is exposed for an extended time to a specific environment ( $T, R H)$. It is also defined as the moisture content at which the water vapor pressure $(\mathrm{Pv})$ in the product is in equilibrium with the vapor pressure of the surrounding environment (BROOKER et al. 1992).

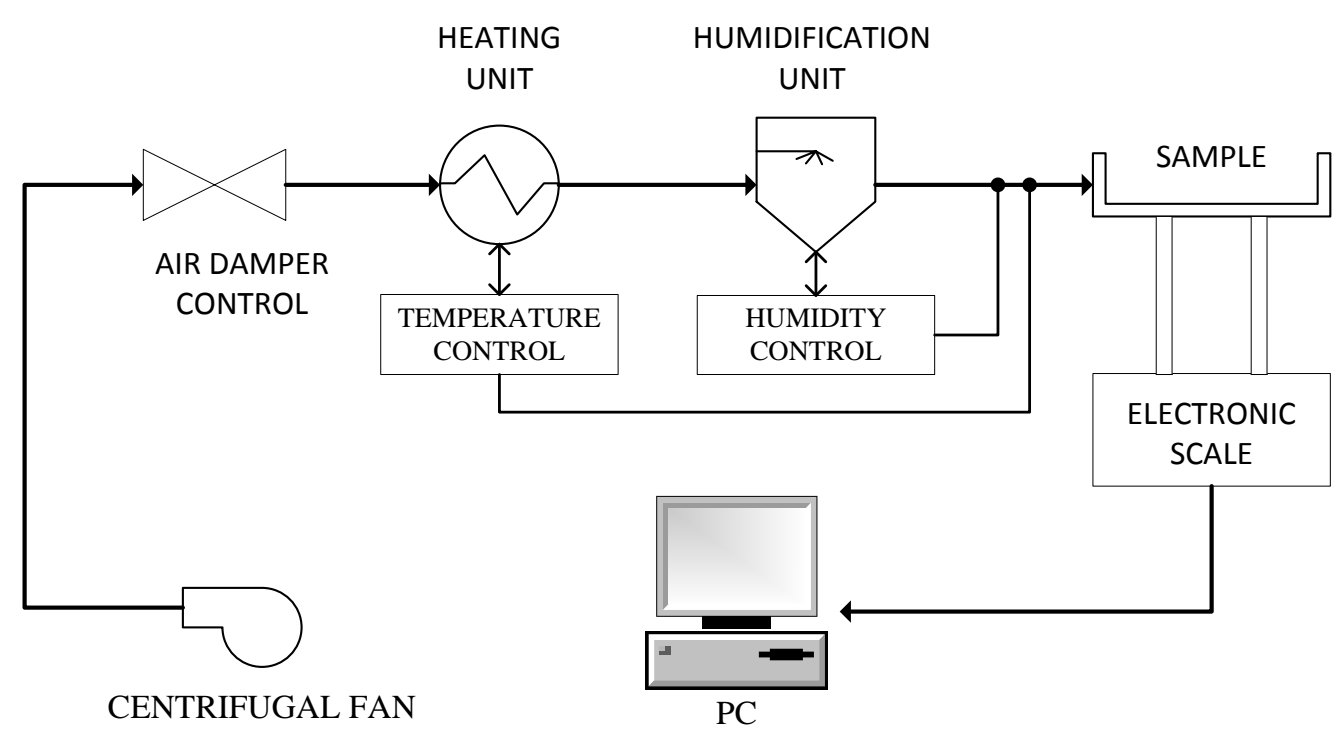

FIGURE 2. Diagram of the drying chamber used. 
The isotherms of equilibrium moisture content were obtained using the dynamic method set up by Roa (PARRA-CORONADO et al., 2008), for which the Experimental Chamber Drying was used. Conditions of temperature $(\mathrm{T})$ and relative humidity $(\mathrm{RH})$ of the air drying equipment was fixed, remaining constant over time; Pellet samples cassava starch $100 \mathrm{~g}$ were placed in a tray, over which the drying air circulates. Isotherms were obtained at four different temperatures for eight different relative humidity, as shown in Table 1. Using a factorial design were obtained a total of 32 assays, of which were performed in duplicate.

TABLE 1. Tests carried to determine the equilibrium moisture content equation.

\begin{tabular}{clllllllll}
\hline Temperature $\left({ }^{\circ} \mathbf{C}\right)$ & \multicolumn{7}{c}{ Air Relative Humidity (\%) } \\
\hline $\mathbf{7 0}^{\circ} \mathbf{C}$ & 5 & 10 & 15 & 23 & 34 & 48 & 70 & 85 \\
$\mathbf{5 5}^{\circ} \mathbf{C}$ & 3 & 8 & 15 & 24 & 34 & 44 & 60 & 88 \\
$\mathbf{4 0}^{\circ} \mathbf{C}$ & 10 & 17 & 24 & 40 & 60 & 73 & 83 & 89 \\
$\mathbf{2 5}^{\circ} \mathbf{C}$ & 8 & 14 & 24 & 30 & 45 & 50 & 74 & 88 \\
\hline
\end{tabular}

To estimate the constants of the equilibrium moisture content equation given by Roa corresponding to cassava starch pellets from experimental data, as well as for other equations, it was used the correlation technique by the least squares and linear regression, using the Excel Solver tool. Equation (1) is the equation proposed by Roa (PARRA-CORONADO et al., 2008).

$$
M e=A \cdot \exp [(B)(C)]
$$

where,

$$
\begin{aligned}
& \mathrm{A}=\left(\mathrm{P}_{0}+\mathrm{P}_{1} \mathrm{HR}+\mathrm{P}_{2} \mathrm{HR}^{2}+\mathrm{P}_{3} \mathrm{HR}^{3}\right) \\
& \mathrm{B}=\left(\mathrm{Q}_{0}+\mathrm{Q}_{1} \mathrm{HR}+\mathrm{Q}_{2} \mathrm{HR}^{2}+\mathrm{Q}_{3} \mathrm{HR}^{3}+\mathrm{Q}_{4} \mathrm{HR}^{4}\right) \\
& \mathrm{C}=\left(\mathrm{T}+\mathrm{Q}_{5}\right)
\end{aligned}
$$

RH: Air Relative humidity (decimal);

T: Air temperature $\left({ }^{\circ} \mathrm{C}\right)$;

Me: equilibrium moisture content $(\mathrm{db})$,

$\mathrm{P}_{0}, \mathrm{P}_{1}, \mathrm{P}_{2}, \mathrm{P}_{3}, \mathrm{Q}_{0}, \mathrm{Q}_{1}, \mathrm{Q}_{2}, \mathrm{Q}_{3}, \mathrm{Q}_{4}$ and $\mathrm{Q}_{5}$ : Constants for each product, obtained by the method of least squares fitting.

\section{Latent heat of vaporization equation}

The latent heat is defined as the energy required to vaporize a unit mass of water of the product that is at a certain moisture content and temperature. For this equation it is not necessary to perform additional experimental tests because it can be determined from the values of the equilibrium moisture content of the product at different temperatures and humidity, for which it is used the method described by BROOKER et al (1992) and DA SILVA et al. (2008), that is presented in [eq. (2)], from which can be determined the latent heat of vaporization depending on the temperature and the product moisture content.

$$
\frac{\mathrm{h}^{\prime} \mathrm{fg}}{\mathrm{hfg}}=\frac{\ln \left(H R_{1} P v s_{1}\right)-\ln \left(H R_{2} P v s_{2}\right)}{\ln \left(P v s_{1}\right)-\ln \left(P v s_{2}\right)}
$$

where,

Pvs: saturated vapor pressure at $\mathrm{T} 1$ and $\mathrm{T} 2\left(\mathrm{~N} \mathrm{~m}^{-2}\right)$ temperatures;

h'fg: latent heat of vaporization of the water contained in the product $\left(\mathrm{kJ} \mathrm{kg}^{-1}\right)$;

hfg: latent heat of vaporization of the free water $\left(\mathrm{kJ} \mathrm{kg}^{-1}\right)$, 
RH: Relative humidity at T1 and T2 (decimal) temperatures.

For each moisture content of the product is possible to determine the value of the equilibrium relative humidity and establish the relationship between the latent heat of vaporization of water in the product and the pure water as a function of moisture content of the product, which have the form exponential in [eq. (3)].

$$
\frac{\mathrm{h}^{\prime} \mathrm{fg}}{\mathrm{hfg}}=1+\alpha \exp (-\beta M)
$$

where,

$\mathrm{M}$ is the product moisture content (db),

$\alpha$ and $\beta$ own product constant (dimensionless), obtained by the method of least squares fitting.

The latent heat of vaporization to the free water (hfg) can be obtained by different equations such as [eq. (4)], given by THOMPSON et al. (1968).

$$
h f g=2500.3-2.09 T
$$

where,

$\mathrm{h} f g$ is obtained in $\mathrm{kJ} \mathrm{kg}^{-1}$ for the temperature $(\mathrm{T})$ in ${ }^{\circ} \mathrm{C}$.

\section{Drying rate equation}

Drying curves for different temperatures and relative humidities and different starch charge densities were obtained, keeping fixed the size and the geometry of the pellets. Weight loss product was recorded in one minute intervals under constant drying conditions shown in Table 2. Using a factorial design were obtained in a total of 24 trials, which were performed in duplicate.

TABLE 2. Tests carried to determine the drying rate equation.

\begin{tabular}{ccc}
\hline Variables & Levels & Values \\
\hline Air Temperature $\left({ }^{\circ} \mathrm{C}\right)$ & 4 & $25 ; 40 ; 55 ; 70$ \\
Air Velocity $\left(\mathrm{m} \mathrm{s}^{-1}\right)$ & 2 & $1.4 ; 3.4$ \\
Starch charge $\left(\mathrm{kg} \mathrm{m}^{-2}\right)$ & 3 & $3.75 ; 6.25 ; 8.75$ \\
Total number of trials & 24 & \\
\hline
\end{tabular}

The drying rate equation express the change in the moisture of the product per unit time as a function of the physical variables which affect it according to the drying system used. Based on theoretical drying equations, ROA (1974) proposed an empirical equation which can be correlated in a simple way the important variables for the natural drying process of cassava bars [eq. (5)]; this equation has particular application in the case of starch pellets drying with tangential airflow.

$$
\frac{d M}{d t}=(M-M e)\left(a_{0}+a_{1} v+a_{2} P v s(1-H R) * M+a_{3} P v s(1-H R)\right)\left(a_{4}+a_{5} C\right)\left(a_{6}+a_{7} P+a_{8} S\right)
$$

where:

$\frac{d M}{d t}$ Variation in moisture content of the product over time $\left(\mathrm{min}^{-1}\right)$;

M: Moisture content of the solid (or product) at a particular instant (db);

Me: equilibrium moisture content (db);

RH: Air Relative humidity (decimal); 
T: Air temperature $\left({ }^{\circ} \mathrm{C}\right)$;

Pvs: Saturated vapor pressure $(\mathrm{Pa})$;

v: Air velocity (m s-1);

$\mathrm{C}$ : Initial charge of the solid $\left(\mathrm{kg} \mathrm{m}^{-2}\right)$;

P: Fraction of voids or porosity of the product (decimal);

S: Geometric solid variable: $\mathrm{S}=1 / \mathrm{L}_{2}+1 / \mathrm{w}_{1}+1 / \mathrm{w}_{2}$;

$\mathrm{L}, \mathrm{w}_{1}$ and $\mathrm{w}_{2}$ : Solid Dimensions (length, width and height respectively) (m);

$\mathrm{a}_{0}, \mathrm{a}_{1}, \mathrm{a}_{2}, \mathrm{a}_{3}, \mathrm{a}_{4}, \mathrm{a}_{5}, \mathrm{a}_{6}, \mathrm{a}_{7}$ and $\mathrm{a}_{8}$ : Constants of the product without physical significance,

obtained by the method of least squares fitting.

\section{Specific Heat equation}

The specific heat is defined as the amount of energy per unit mass necessary to increase a degree of a given body temperature and depends on the product composition and the temperature at which it is located. Modulated Differential Scanning Calorimetry technique (MDSC) was used for obtaining experimental data to fit an equation of specific heat. The equipment used was a differential scanning calorimeter DSC 2910, Modulated DSC TA Instrument, which records specific heat data for the starch sample as a function of temperature; the determination was done for four moisture contents as shown in Table 3.

TABLE 3. Tests carried out to determine the specific heat equation.

\begin{tabular}{lll}
\hline \multicolumn{1}{c}{ Variables } & \multicolumn{1}{c}{ Values } \\
\hline Sample humidity (dry basis) & $0.040 ; 0.245 ; 0.423 ; 0.746$ \\
Sample humidity (wet basis) & $3.8 \% ; 19.7 \% ; 29.7 \% ; 42.7 \%$ \\
Sample Temperature Range $\left({ }^{\circ} \mathbf{C}\right)$ & $20-70$ & \\
\hline
\end{tabular}

The general form of the specific heat equation is shown in [eq. (6)].

$$
C_{P}=o\left(\frac{M}{1+M}\right)+p T+q
$$

where,

Cp the specific heat of the product $\left(\mathrm{kJ} \mathrm{kg}^{-1}{ }^{\circ} \mathrm{C}^{-1}\right)$;

$\mathrm{M}$ the product moisture content $(\mathrm{db})$;

T the product temperature $\left({ }^{\circ} \mathrm{C}\right)$,

$\mathrm{o}, \mathrm{p}$ and q product constants (dimensionless), obtained by the method of least squares fitting.

\section{RESULTS AND DISCUSSION}

\section{Equilibrium moisture content equation.}

The equilibrium moisture content (Me) on dry basis to starch pellets at different temperatures (T) and relative humidity (RH) of air was found using the dynamic method. From the data obtained and using a correlation technique by nonlinear least squares, the values of the constants in the equation of the equilibrium moisture content [eq. (7)] were obtained. 


$$
M e=0.01 \cdot A \cdot \exp [(B)(C)]
$$

where,

$$
\begin{aligned}
& A=\left(727.44 H R+559.9 H R^{2}+475.64 H R^{3}\right) \\
& B=\left(-0.0143-0.071 H R+0.132 H R^{2}-0.157 H R^{3}+0.0931 H R^{4}\right) \\
& C=(T+81.64)
\end{aligned}
$$

From this equation can be generated isotherms of equilibrium moisture content for cassava starch pellets (Figure 3), which have sigmoidal shape, which is the typical behavior showed by different authors for other products (BROOKER et al. , 1992; PARRA-CORONADO et al, 2008;. CHAYJAN \& ESNA- ASHARI, 2010). Regression analysis showed no significant differences between the experimental data and those generated by the model.

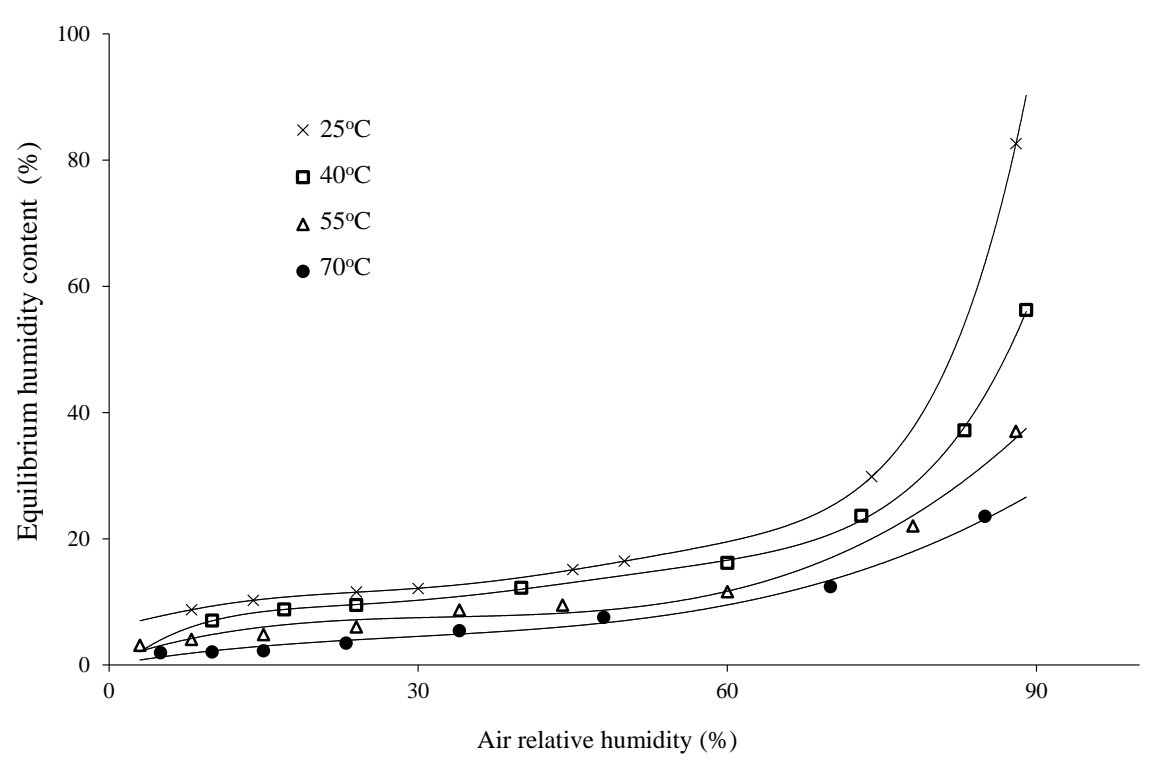

FIGURE 3. Isotherms of equilibrium moisture content for cassava starch pellets. Curves estimated by the model and experimental data (points) for different temperatures.

\section{Latent heat of vaporization equation}

It was used the presented methodology and correlation technique by nonlinear least squares regression, was obtained the values of the constants in [eq. (3)], relating to the latent heat of vaporization of the water contained in the starch pellets and the latent heat of vaporization obtained of pure water, which are presented in [eq. (8)].

$$
\frac{h f g}{h f g}=1+1.8597 \exp (-0.1075 M)
$$

The latent heat of vaporization of pure water (hfg) is calculated using [eq. (6)], finally obtaining the [eq. (9)], with which it is possible to calculate the latent heat of vaporization of the water contained in the starch pellets. In this equation the curve shown in Figure 4, with reference temperatures between $25{ }^{\circ} \mathrm{C}$ and $70{ }^{\circ} \mathrm{C}$, wherein shows that the data generated by the equation stored a correlation to the experimental results as indicated in $\mathrm{R}^{2}=0.99$. The results obtained as the respective equation, consistent with the results obtained by DA SILVA et al. (2008) and with those reported by PARRA-CORONADO et al. (2008). 


$$
h f g=(2500.3-2.09 T)(1+1.8597 \exp (+0.1075 M))
$$

where,

h'fg the latent heat of vaporization of the water contained in the cassava starch pellets $\left(\mathrm{kJ} \mathrm{kg}^{-1}\right)$;

$\mathrm{T}$ Temperature $\left({ }^{\circ} \mathrm{C}\right)$, and

M moisture content of the starch (db).

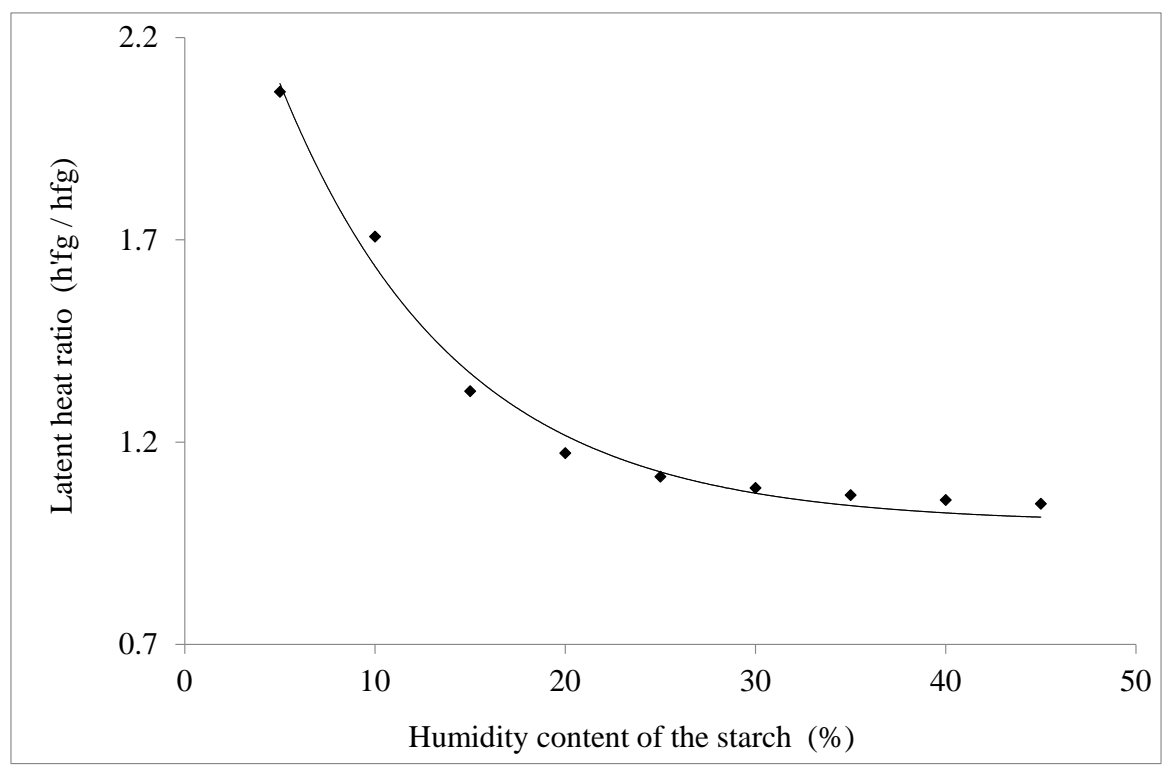

FIGURE 4. Comparison between experimental and calculated data for latent heat of vaporization of cassava starch pellets.

\section{Drying rate equation}

For each combinations of variables used one drying curve was obtained by recording the moisture content $(\mathrm{M})$ on a dry basis over time. Using the correlation technique for nonlinear least squares regression, the values of the constants for the drying rate equation given by ROA (1974), which was adapted in this research for cassava starch pellets was obtained the [eq. (10)]:

$$
\frac{d M}{d t}=(M-M e)(0.9817+0.1172 v-0.0957 P V S(1-H R) \cdot M+0.1249 P V S(1-H R))(0.2121-0.0144 C)
$$

where,

$\mathrm{M}$ is the moisture content of the solid (db);

Me the content of the equilibrium moisture (db) [eq. (7)];

$\mathrm{RH}$ the air relative humidity (decimal);

T the Air temperature $\left({ }^{\circ} \mathrm{C}\right)$;

Pvs the saturated vapor pressure $(\mathrm{Pa})$;

$\mathrm{v}$ the Air velocity $\left(\mathrm{m} \mathrm{s}^{-1}\right)$, and

$\mathrm{C}$ the solid charge $\left(\mathrm{kg} \mathrm{m}^{-}{ }^{2}\right)$. 

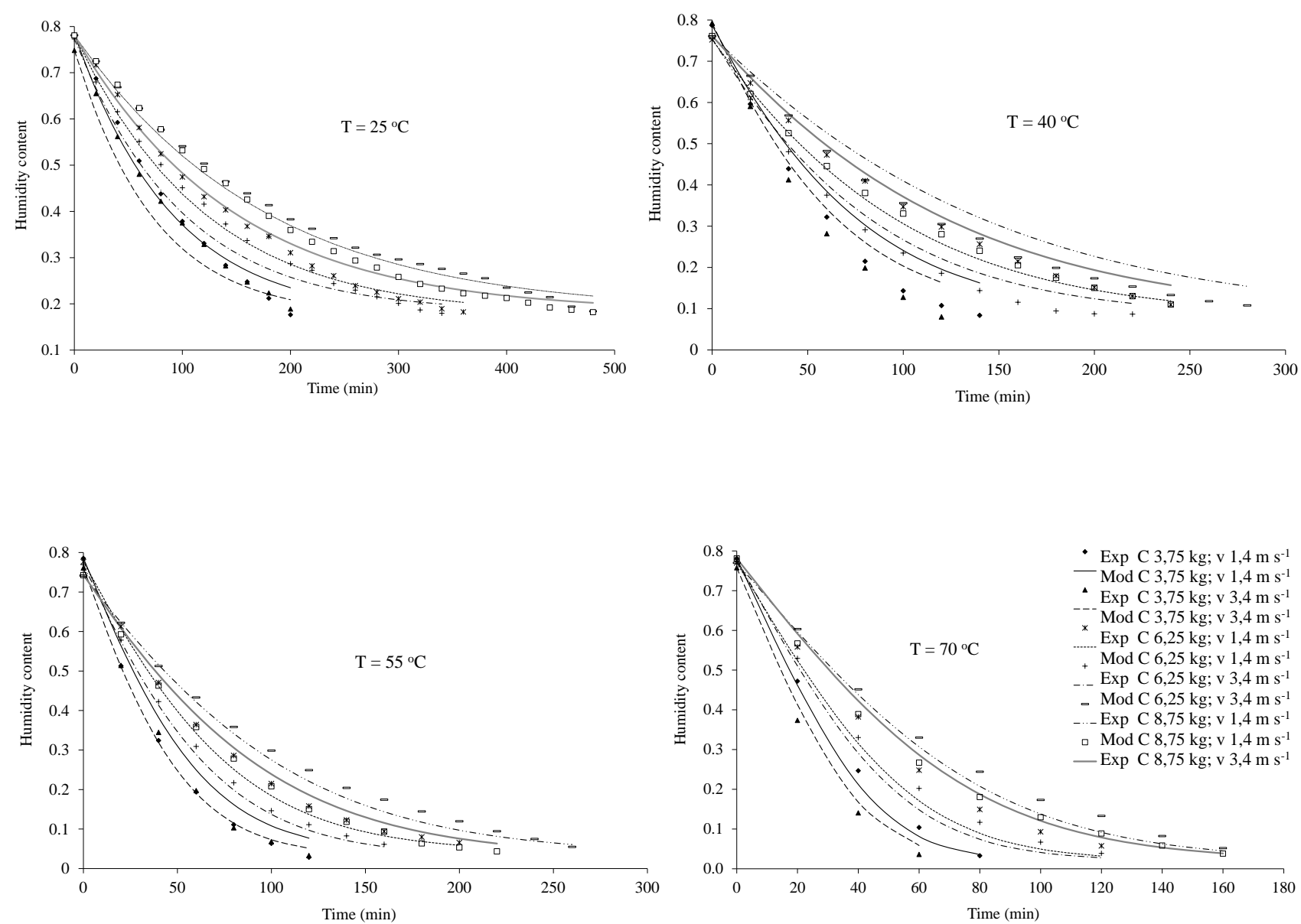

FIGURE 5. Comparison of experimental data with the drying curves generated by the model for cassava starch pellets.

From [eq. (10)] can be generated the drying curves under different speed, humidity content, air temperature and starch charge density (Figure 5). Table 4 shows the coefficients of determination $\left(\mathrm{R}^{2}\right)$ corresponding to the drying curves obtained by the adjusted model.

Table 4. Coefficients of determination $\left(\mathrm{R}^{2}\right)$ for the drying curves of cassava starch pellets, obtained by the model.

\begin{tabular}{ccccc}
\hline \multirow{2}{*}{ Temperature $\left({ }^{\circ} \mathrm{C}\right)$} & $\begin{array}{c}\text { Drying Rate } \\
\left(\mathrm{m} \mathrm{s}^{-1}\right)\end{array}$ & 3.75 & 6.25 & 8.75 \\
\cline { 3 - 5 } 25 & 1.4 & 0.988 & 0.988 & 0.994 \\
& 3.4 & 0.977 & 0.976 & 0.987 \\
\multirow{2}{*}{40} & 1.4 & 0.998 & 0.992 & 0.997 \\
& 3.4 & 0.999 & 0.999 & 0.997 \\
55 & 1.4 & 0.997 & 0.998 & 0.997 \\
& 3.4 & 0.997 & 0.999 & 0.999 \\
& 1.4 & 0.997 & 0.992 & 0.998 \\
& 3.4 & 0.997 & 0.996 & 0.997 \\
\hline
\end{tabular}


The $\mathrm{R}^{2}$ obtained show that the model coefficients of drying rate obtained from the experimental data allows the development of a model that adequately represents the drying of cassava starch pellets, to predict the behavior of the drying process under different conditions, resulting in a tool to support the design and management of the systems and the processes of drying, which leads to savings in time and resources. The results have similar behaviors to those reported for different products by different authors as VEGA \& LEMUS (2006), PARRA-CORONADO et al. (2008), MONTES MONTES et al. (2008), DALPASCUALE et al. (2009) and DALPASQUALE \& SPERANDIO (2010).

\section{Specific heat equation}

Modulated Differential Scanning Calorimetry Technique (MDSC) was used in four moisture contents to determining the equation of specific heat (Cp) on wet basis of cassava starch pellets in the range from $25{ }^{\circ} \mathrm{C}$ to $75^{\circ} \mathrm{C}$ of temperature. Using the technique of the least squares regression [eq. (11)] was obtained, which relates the specific heat of the cassava starch pellets as a linear function of the temperature and humidity of the solid.

$$
C p=0.014\left(\frac{M}{1+M}\right)+0.005 T+0.965
$$

where,

Cp the specific heat of starch $\left(\mathrm{kJ} \mathrm{kg}^{-1}{ }^{\circ} \mathrm{C}^{-1}\right)$;

$\mathrm{M}$ the moisture content of the starch $(\mathrm{db})$ and the starch temperature $\mathrm{T}\left({ }^{\circ} \mathrm{C}\right)$.

Data generated by the equation are highly correlated with the experimental results as indicated by the $\mathrm{R}^{2}=0.996$ (Figure 6).

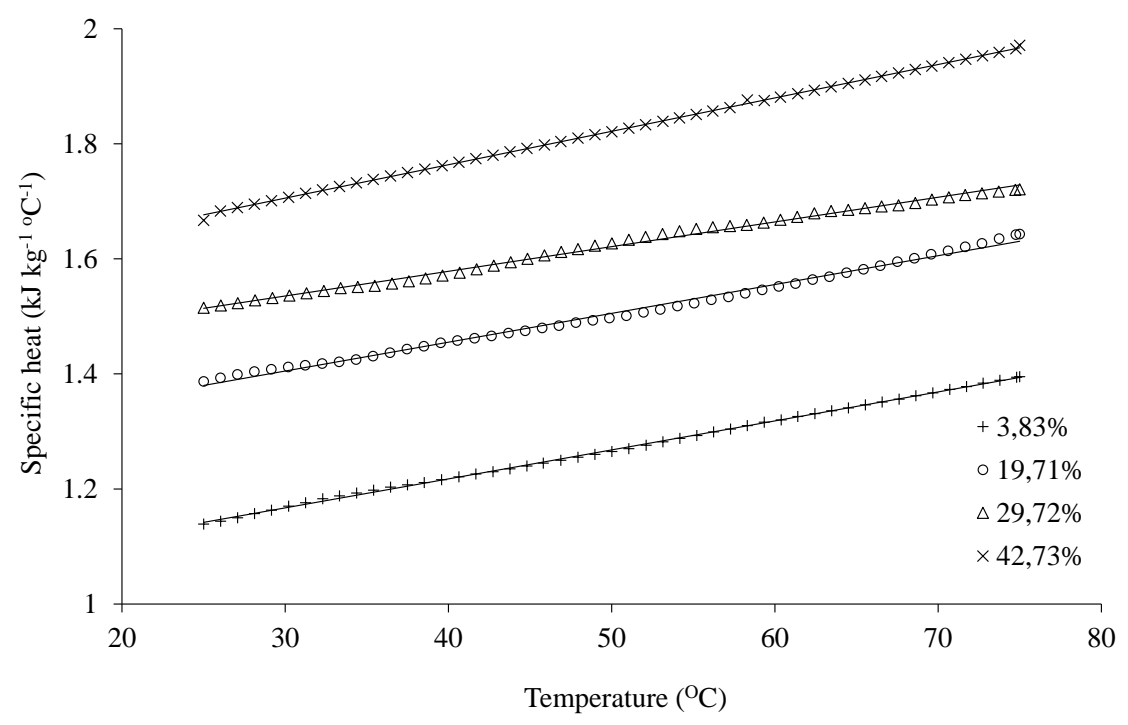

FIGURE 6. Comparison between experimental and calculated data for the specific heat of cassava starch pellets.

\section{CONCLUSIONS}

The equations of the parameters found for the mathematical representation of the drying cassava starch pellet, allows predicting successfully the behavior of this product when it is subjected to a mechanical drying process, with a parallel air flow to the trays containing the pellets, it constitutes a fundamental tool that will allow obtaining efficient and economical drying systems designs and establish the best way to operate efficiently. The obtained equations provide values that fit well with the respective experimental data. 
Drying times obtained in the present investigation (from 60 to $470 \mathrm{~min}$, depending on the temperature and air flow rate), allow to foresee that the new technique of preformed starch by forming pellets, contribute to obtaining more efficient designs of dryers, as well as operating systems that will reduce the drying time of the product.

\section{REFERENCES}

ALARCON, F. \& DUFOUR, D. Almidón agrio de yuca en Colombia. Cali, Colombia: CIAT. 2002. ARISTIZABAL, J.; MORENO, F. L.; BASTO, G. Estudio de una nueva técnica e implementación de una línea pilto de proceso para la obtención de dextrinas a partir de almidón de yuca. Ingeniería e Investigación , 27 (2), p 26-33, 2007.

BROOKER, D. B.; BAKKER-ARKEMA, F. W.; HALL, C. W. Drying and storage of grains and oilseeds. An AVI book, New York: Published by Van Nostrand Reinhold. 1992. 450p.

CENKOWSKI, S.; JAYAS, D.S.; PABIS, S. Deep-Bed Grain Drying - A Review of particular theories. Drying Technology, v.11, n.7, p.1553-1581, 1993.

CEBALLOS, H. La yuca en Colombia y el mundo: nuevas perspectivas para un cultivo milenario. Cali, Colombia: CIAT. 2002.

CHAYJAN, R.A.; M. ESNA-ASHARI, M. Modeling of heat and entropy sorption of maize (cv. Sc704): neural network method. Res. Agr. Eng., v.56, n.2, p.69-76, 2010.

DALPASQUALE, V.A; SPERANDIO, D. Modelo de simulação de secagem de produtos agrícolas usando entalpia do ar constante. Eng. Agríc., Jaboticabal, v.30, n.4, p.726-731, 2010.

DALPASQUALE, V.A.; SPERANDIO, D.; MONKEN E SILVA, L.H. Fixed-bed drying simulation with constant enthalpy, using the improved Michigan State University model. Acta Scientiarum Technology, Maringá, v.32, n.3, 2009.

DA SILVA, W. P.; SILVA, C. M. D. P. S. E; PRECKER, J. W.; SILVA, D. D. P. S. E. Influência da temperatura do ar de secagem no calor latente de vaporização de água em feijão macassar (Vigna unguiculata (L.) Walp.), variedade sempre-verde. Eng. Agríc., Jaboticabal, v.28, n.2, p.315-324, 2008.

MONTES MONTES, E.J.; TORRES GALLO, R.; ANDRADE PIZARRO, R.D.; PÉREZ SIERRA, O.A.; MARIMON ESCOBAR, J.L.; MEZA HERAZO, I.I. Modelado de la cinética de secado de ñame (dioscorea rotundata) en capa delgada. Revista Ingeniería e Investigación, v.28 n.2, p.45-52, 2008.

PARRA-CORONADO, A.; ROA-MEJÍA, G.; OLIVEROS-TASCÓN, C.E. SECAFÉ Parte I: Modelamiento y simulación matemática en el secado mecánico de café pergamino. Revista Brasileira de Engenharia Agrícola e Ambiental. Campina Grande, PB., v.12, n.4, p.415-427, 2008.

ROA, G. Natural drying of cassava. Thesis Ph.D. Department of Agricultural Engineering, Michigan State University, USA. 1974. 227 p.

THOMPSON, T.L. PEART, R.M.; FOSTER, G.H. Mathematical simulation of corn drying - A new model. Transaction of the ASAE, v.11, n.4, p.582-586, 1968.

VEGA, A.; LEMUS, R. Modelado de la cinética de secado de papaya chilena (basconcellea pubescens). Información tecnológica, v.17, n.3, pp. 23-31, 2006. 